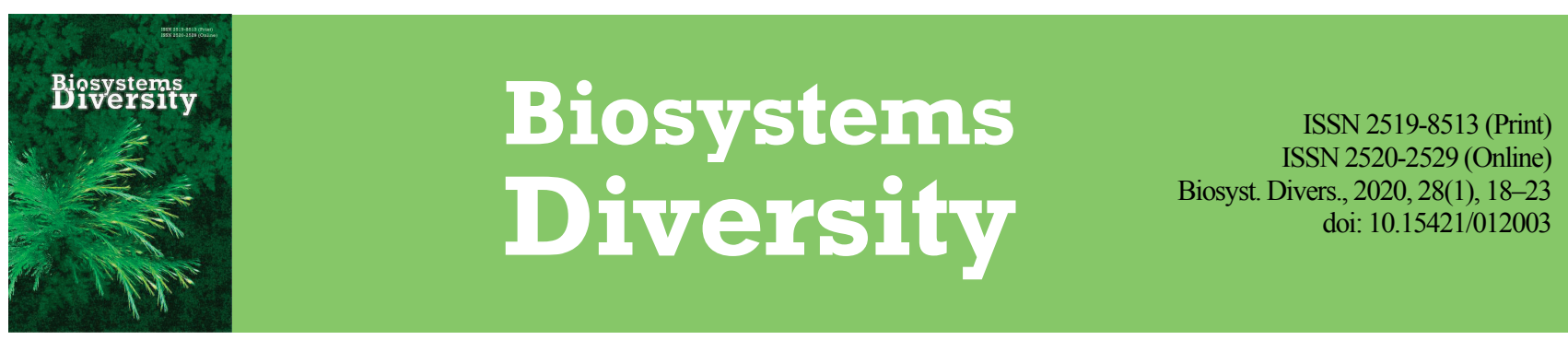

\title{
Morphological variation of Varroa destructor (Parasitiformes, Varroidae) in different seasons
}

\author{
V. O. Yevstafieva*, L. M. Zaloznaya**, O. S. Nazarenko*, V. V. Melnychuk*, A. G. Sobolta*** \\ *Poltava State Agrarian Academy, Poltava, Ukraine \\ **Schmalhausen Institute of Zoology National Academy of Sciences of Ukraine, Kyiv, Ukraine \\ ***Stepan Gzhytskyj Lviv National University of Veterinary Medicine and Biotechnologies, Ukraine
}

Article info

Received 11.01.2020

Received in revised form 08.02.2020

Accepted 09.02.2020

Poltava State Agrarian Academy, Skovorody st., 1/3, Poltava, 36003, Ukraine. Tel.:+38-050-183-78-78 E-mail:evstva@ukr.net

Schmalhausen Institute of Zoology National Academy of Sciences of Ukraine, B. Khmelnytskogo st., 15 , Kyiv, 01601, Ukraine.

Tel.:+38-066-714-51-62.

E-mail: zaloznaluda@gmail.com

Stepan Gzhytskyj Lviv National University of Veterinary Medicine and Biotechnologies, Pekarska st.

50, Lviv, 79000, Ukraine.

Tel.: +38-097-702-10-05.

E-mail:andreu_drams@ukr.net
Yevstafieva, V. O., Zaloznaya, L. M., Nazarenko, O. S., Melnychuk, V. V., \& Sobolta, A. G. (2020). Morphological variation of Varroa destructor (Parasitiformes, Varroidae) in different seasons. Biosystems Diversity, 28(1), 18-23. doi:10.15421/012003

Varroosis is one of the most dangerous and common diseases of honey bees (Apis mellifera Linnaeus, 1758) worldwide, caused by gamasid mites of the species Varroa destructor Anderson and Trueman, 2000. This external parasite is widespread and adapted to the climate conditions of most countries of the world, and it can infect bees at any life stage. It parasites on worker bees, male and queen bees, larvae and pupae, feeding on their hemolymph and fat bodies, causing lower survival rates and lower density of bee colonies, decreasing the bees' life span. Here, we studied the specifics of the seasonal variation of female $V$. destructor mites, obtained from honey bees, by the morphological characters of mites belonging to the summer and winter generations, and their differences were established. Using the methods of multivariate statistics, we found significant differences between the summer (June-July) and winter (October-November) morphotypes of $V$. destructor mites. There are differences between the seasonal samples by 12 morphological characters of the parasite, namely the width of dorsal shield, width of dorsoventral shield, number of pores on sternal shield, length of tarsus and macrochaeta IV, and distances between setae of gnathosoma. Processing the seasonal samples of mites with discriminant analysis resulted in differences by 11 morphological characters including the length of dorsal shield, number of lancet setae, length and width of genitoventral shield, width of anal shield, number of setae and pores on sternal shield and distance between setae of gnathosoma. In general, the summer females are smaller and elongated compared to winter females, with larger genitoventral shield and shorter legs. The mites of summer and winter generations are adapted to different seasons: the summer mites to the reproductive period, the winter generation to overwintering on bees. The ratio of morphotypes in female $V$. destructor mites is observed to change during the year, from $20.2 \%$ winter morphotype in summer generation to $20.7 \%$ summer morphotype in winter mites. Studying the influence of acaricides on the distinguished morphotypes is a promising approach to improve pest control measures against varroosis of honey bees.

Keywords: varroosis; Apis mellifera; female mites; morphotype; seasonal adaptation.

\section{Introduction}

The honey bees evolved as eusocial animals to better adapt to their habitat conditions and widen their species range significantly (Kovalskyi et al., 2018; Kovalchuk et al., 2019; Vishchur et al., 2019). One of the adaptations was the genetically determined necessity to live as a whole complex super-organism, a bee colony. Not a single one of its structural elements (the queen, workers and male bees) can survive on its own. This life form ensured the continued success of these bees as a species. The colony is composed of thousands of specimens per one queen, and it can persist in the most unfavourable environmental conditions and still succeed in reproducing (Delaney et al., 2010; Bloch \& Grozinger, 2011; Hewlett et al., 2018; Shell \& Rehan, 2018). The honey industry struggles with huge economic losses caused by the infectious and non-infectious diseases of bees and their offspring. Varroosis is one of such afflictions which pose a global problem for apiculture, weakening and reducing the number of bee colonies, negatively affecting the environment and decreasing the yield of entomophilous crops and overall productivity of the industry (Boecking \& Genersch, 2008; Dahle, 2010; Rosenkranz et al., 2010; Nazzi et al., 2012; Affognon et al., 2015). In long-term studies it was confirmed that varroosis is the most widely spread mite infection of honey bees of the species Apis mellifera Linnaeus, 1758. The infection can become panzootic, acting in all habitats the mites can possibly colonize (Akimov et al., 2004; Le Conte et al., 2010; Akinwande et al., 2012; Nazzi \& Le Conte, 2016; Rinkevich et al., 2017).
The bee parasites of the genus Varroa Oudemans, 1904 are members of the family Varroidae which infect colonies of bees of the genus Apis Linnaeus, 1758. There are six species of two genera of these specialized mites: $V$. destructor Anderson et Trueman, 2000, $V$. jacobsoni Oudemans, 1904, V. underwoodi Delfinado-Baker et Aggarwal, 1987, V. rindereri De Gurman et Delfinado-Baker, 1996, Euvarroa sinhai Delfinado et Baker, 1974, E. wongsirii Lekprayoon et Tangkanasing, 1991 (Oudemans, 1904; Woo, 1992; Anderson et al., 1997; Anderson \& Trueman, 2000; Dadgostar \& Nozari, 2018). Varroa destructor, V. jacobsoni and $V$. underwoodi can also infect colonies of Apis c. cerana Fabricius, 1793 bees. $V$. rindereri only parasitizes $A$. koschevnikovi Enderlein, 1906 bees on Borneo and Philippine islands (Anderson \& Trueman, 2000). Euvarroa sinhai infects bees of the species A. florea Fabricius, 1787 and A. mellifera, and it is recorded in India, Sri Lanka, Thailand and Iran (Mossadegh, 1990; Akimov et al., 1993). The mite species E. wongsirii Lekprayoon et Tangkanasing, 1991 was found on $A$. andreniformis Smith, 1858 bees in Thailand, Malaysia, India and Indonesia (Lekprayoon \& Tangkanasing, 1991; Otis \& Kraly, 2001).

However, it has been confirmed, that the most frequent parasites of $A$. mellifera honey bees are mites of the species $V$. destructor. Their life cycle includes the obligate change of hosts of different stages of development and physiological state. Hence, the mites do not parasitize single specimens of bees, but the whole colony. This is confirmed also by the fact that the development of varroosis results not in death of single bees, but all bees of a colony. This kind of parasitism is induced 
by the relative stability of the beehive conditions, sustained by bees even in winter. That is the reason for the high pathogenicity of $V$. destructor mites to the honey bees, and for the complicated pest control measures (Akimov et al., 1988; Akimov \& Kiryushyn, 2010; Akimov \& Korzh, 2012; Oddie et al., 2019).

It is known that Varroa destructor (= Varroa jacobsoni auct.) was found for the first time in nests of the Indian honey bee, Apis cerana indica Fabricius, 1798. Both species (V. destructor and A. cerana) exist in ecological balance with each other (Peng et al., 1987; Rath, 1999; Oldroyd, 1999; Nanork et al., 2007). However, the anthropogenic influence on the natural habitats of $A$. cerana and the introduction of the more productive honey bee species, $A$. mellifera, allowed the parasitic species to infect the latter bee, significantly increasing the mite's range (Delfinado, 1963; Griffiths \& Bowman, 1981; Kuznetsov, 2005; Kuznetsov \& Lelej, 2005).

The expansion of this dangerous parasite, which successfully adapted to a new host and new climate zones, is why the intraspecific morphological differentiation of $V$. destructor is of scientific interest. Thus, there have been reports of morphological variability of mites from different host species and continents (Delfinado-Baker, 1988; DelfinadoBaker \& Houk, 1989; Akimov \& Benedyk, 2004). Also, there are observations of intraspecific regional complexes of $V$. destructor and the sexual and seasonal morphological variations of mites. The seasonal variation is described as numbers of anomalies in the studied characters of $V$. destructor females, which increase during the spring and summer, and decrease from summer to autumn (Delfinado \& Houck, 1989; Akimov et al., 2004; Maggi et al., 2009; Abou-Shaara \& Tabikha, 2017). Although two mite morphotypes (summer and winter) have been distinguished in previous studies, no strong differentiation has been described for them. Hence, the morphological characters of $V$. destructor mites which parasite on $A$. mellifera bees in different seasons should be studied in detail. That will allow us to determine the mite's capability of adaptation, and to develop new morphotype-specific approaches in order to improve the effectiveness of pest control measures. The aim of the present work was to study the seasonal specifics of variation in $V$. destructor by the morphological characters of mites from the summer and winter generations, and to find out previously undiscovered differences between them.

\section{Materials and methods}

The specifics of morphology and variation of $V$. destructor females were studied on samples of mites collected in 2018 in colonies of A. mellifera bees during two seasons, summer (June and July) and winter (October and November). Mites were collected at private honey farms in Poltava region of Ukraine. Mite specimens were fixed in $70 \%$ ethanol and mounted on permanent slides in Hoyer's mounting medium (Zahvatkin, 1941). Biometrical studies of $V$. destructor females were conducted using a Biolam L-211 microscope. Each sample consisted of 120 female mites, 240 mites were measured in total. The morphological variation was studied by the metrical and qualitative characters, 10 of which paired. Measurements were taken from both the level and right sides of body. Overall, data on 19 morphological characters was statistically processed (Fig. 1).

Statistical processing of data was conducted using the method of principal components, one-way dispersion analysis and the Tukey test. The calculations were done using the statistical packets PAST 3 (Hammer et al., 2001) and Statistica 12 for Windows (StatSoft, Inc., USA).

\section{Results}

According to the eigenvalues (PCA), the first three components explain $68.6 \%$ of the total variance (Table 1). Analysis of eigenvalues of the first (I) principal component, which describes $50.1 \%$ of the total variance, shows that the main positive values belong to the size of the dorsal shield (characters 1 and 2), sizes of shields on the ventral side of body (characters 5-6, 9-10). The second (II) principal component explains $11.2 \%$ of the total variance, and the major positive values in it are of the length of the dorsal shield (character 1), sizes of shields on the ventral side of the body (characters $5-6,8,11$ ), width of the gnathosome (character 12), and distance between the third pair of setae of the gnathosome (character 29). The maximum negative value in that component belongs to the character 2 , the width of the dorsal shield. The third (III) principal component explains only $7.3 \%$ of the total variance. Its main values belong to the size of the genitoventral shield (character 9-10), and distance between the third pair of setae of the gnathosome (character 29).

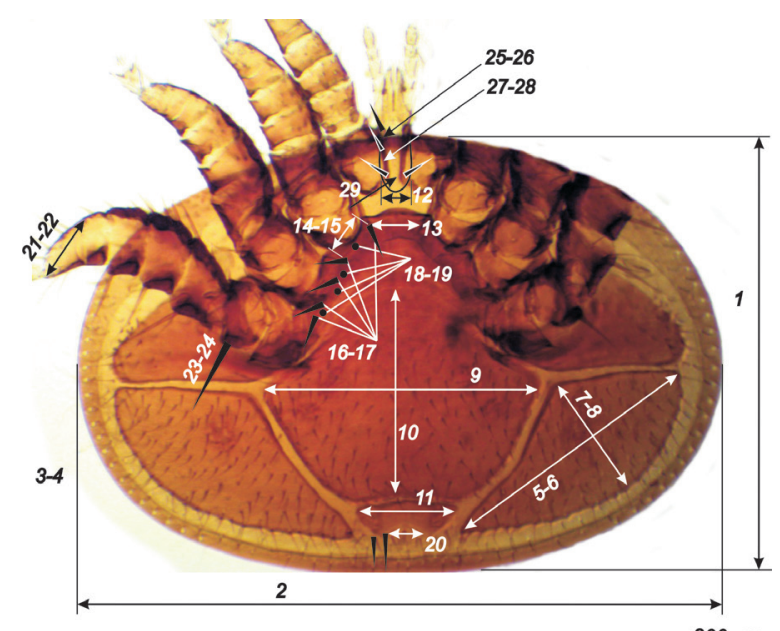

$200 \mu m$

Fig. 1. Morphological characters of female Varroa destructor mites: 1-length of dorsal shield; 2 - width of dorsal shield; 3-4-number of lancet setae; 5-6-width of pleural shield; 7-8-length of pleural shield;

9 - width of genitoventral shield; 10 - length of genitoventral shield;

11 - width of anal shield; 12 - width of gnathosome base; 13 - distance between the first pair of setae of sternal shield; $14-15$ - distance between the first and second pairs of setae of sternal shield; $16-17-$ number of

setae on sternal shield; $18-19$ - number of pores on sternal shield;

20 - distance between anal setae; $21-22$ - length of tarsus IV; 23-24-

length of macrochaeta IV; 25-26-distance between first and second setae of hypostome; $27-28$ - distance between second and third setae of hypostome; 29 - distance between third pairs of setae of hypostome

On the scatterplots in the space of three principal components it can be seen that the data from the different seasonal samples overlap strongly. That is, they are not distinguished in the space of these components (Fig. 2).

The next stage of analysis was changing the absolute values of characters with their average values, excluding all quantitative characters (2$3,16-19)$. Only one principal component was obtained then, explaining $100 \%$ of the total considered variance. The main positive values in the difference between the summer and winter mite generations belonged to the following characters: length of dorsal shield (character 1), length and width of genitoventral shield (characters 9, 10), distance between second and third setae of hypostome (characters 27-28). The component's value was negatively affected by the width of dorsal shield (character 2 ) and length of macrochaeta IV (characters 23, 24) (Table 2).

Interestingly, the increasing length of the dorsal shield is associated with the decreasing width of the dorsal shield, according to that component. The winter and summer generations of mites do not overlap in the space of the first principal component. Considering the eigenvalues in that component, it can be said that the summer females are smaller, more elongated, with larger genitoventral shield and shorter legs. The winter mites are, in contrast, flatter, with smaller genitoventral shield and longer legs.

The average values of morphological characters of mites sampled in winter and summer were compared using the Tukey test. The results showed differences between these samples by 12 morphological characters (Table 3). These are, firstly, width of dorsal shield (character 1), width of dorsoventral shield (character 9), number of pores on the ternal shield (characters 18, 19), length of tarsus and macrochaeta IV (characters 2124) and distances between the setae of gnathosome (characters 25, 27-29). Analysis of the obtained data showed that the winter females are elongated, with smaller genitoventral shield, more pores on the sternal shield and longer legs. Summer samples are, by contrast, wider with wider dorsal shield and shorter legs. 
Table 1

Eigenvalues of morphological characters of Varroa destructor female mites of seasonal samples in I, II and III principal components

\begin{tabular}{|c|c|c|c|c|c|c|c|}
\hline \multirow{2}{*}{ Character } & \multicolumn{3}{|c|}{ Principal component } & \multirow{2}{*}{ Character } & \multicolumn{3}{|c|}{ Principal component } \\
\hline & I & II & III & & I & II & III \\
\hline 1 & $0.2685^{* *}$ & $0.2694 * *$ & -0.0890 & 15 & 0.0068 & -0.0181 & -0.0007 \\
\hline 2 & $0.7140 * * *$ & $-0.6671 * * *$ & 0.1371 & 20 & 0.0016 & -0.0062 & 0.0073 \\
\hline 5 & $0.3859 *$ & $0.3852 *$ & 0.1052 & 21 & 0.0282 & 0.0018 & -0.0051 \\
\hline 6 & $0.3640 * * *$ & 0.3978* & 0.1153 & 22 & 0.0240 & 0.0006 & -0.0446 \\
\hline 7 & 0.1213 & 0.1343 & 0.0758 & 23 & 0.0177 & -0.0371 & -0.0255 \\
\hline 8 & 0.1012 & $0.4276^{* *}$ & -0.1271 & 24 & 0.0260 & -0.0032 & 0.0024 \\
\hline 9 & $0.2603 * *$ & 0.0270 & $0.3676^{* * *}$ & 25 & 0.0019 & -0.0054 & -0.0017 \\
\hline 10 & $0.1980 * *$ & 0.1380 & $0.8587 * * *$ & 26 & 0.0041 & -0.0094 & 0.0199 \\
\hline 11 & 0.0297 & $0.2542 *$ & -0.1599 & 27 & 0.0045 & -0.0037 & 0.0050 \\
\hline 12 & 0.0136 & $0.2563^{* *}$ & -0.1065 & 28 & -0.0001 & 0.0062 & 0.0017 \\
\hline 13 & 0.0080 & -0.0383 & 0.0450 & 29 & -0.0002 & 0.3420 ** & $0.3271 * *$ \\
\hline 14 & 0.0351 & -0.0004 & 0.0559 & $\%$ of total variance & 50.072 & 11.1910 & 7.3070 \\
\hline
\end{tabular}

Note: significance levels $*-\mathrm{P}<0.05,{ }^{*}-\mathrm{P}<0.01,{ }^{* * *}-\mathrm{P}<0.001$.

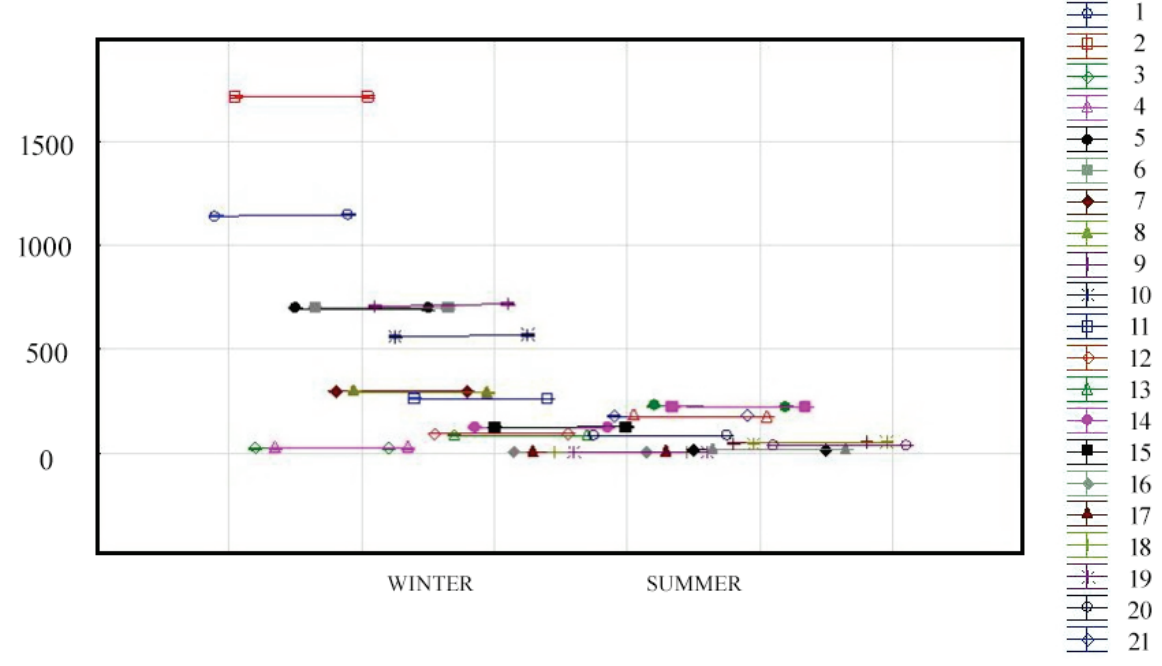

Fig. 2. Scatterplot of average values of morphological characters in summer and winter female Varroa destructor mites

Table 2

Eigenvalues of morphological characters of female Varroa destructor mites of seasonal samples in I principal component

\begin{tabular}{cccc}
\hline Character & $\begin{array}{c}\text { Principal } \\
\text { component I }\end{array}$ & Character & $\begin{array}{c}\text { Principal compo- } \\
\text { nent I }\end{array}$ \\
\hline 1 & $0.263^{* * *}$ & 15 & 0.131 \\
2 & $-0.603^{* *}$ & 20 & -0.004 \\
5 & -0.036 & 21 & -0.076 \\
6 & -0.108 & 22 & 0.080 \\
7 & -0.020 & 23 & $-0.135^{* *}$ \\
8 & -0.129 & 24 & $-0.164^{* * *}$ \\
9 & $0.550^{* * *}$ & 25 & 0.031 \\
10 & $0.207^{* *}$ & 26 & -0.009 \\
11 & -0.091 & 27 & $0.170^{* * *}$ \\
12 & -0.067 & 28 & $0.156^{* *}$ \\
13 & -0.031 & 29 & 0.040 \\
14 & 0.038 & \% of total variance & 1.000 \\
\hline
\end{tabular}

Note: significance levels $* *-\mathrm{P}<0.01, * * *-\mathrm{P}<0.001$.

The morphological characters of mites of the seasonal samples were analyzed with discriminant analysis. The results showed that the difference between samples is statistically significant (Wilks' Lambda $=$ $0.539 ; \mathrm{P}=1.2 * 10^{-5}$ ). Only one canonical axis was determined with the total dispersion of $0.972 \%$.

Thus, the seasonal samples are statistically different by 11 morphological characters. The analysis of coefficients with the first and only canonical axis showed that the winter and summer mites are different by the following characters: length of dorsal shield (character 1), number of lancet setae (character 4), length and width of genitoventral shield (characters 9,10), width of anal shield (character 11), number of setae and pores of sternal shield (characters 16, 18, 19) and distance between the gnathosome setae (characters 27-29) (Table 4).
Table 3

Average values of morphological characters and results of comparison of female Varroa destructor mites in seasonal samples

\begin{tabular}{cccc}
\hline Character & Winter & Summer & Winter-summer \\
\hline 1 & 1140 & 1146 & $*$ \\
2 & 1714 & 1712 & - \\
7 & 298 & 297 & - \\
8 & 295 & 292 & - \\
9 & 705 & 719 & $* * *$ \\
10 & 561 & 566 & - \\
11 & 263 & 260 & - \\
18 & 6.4 & 5.9 & $* * *$ \\
19 & 6.3 & 5.9 & $*$ \\
20 & 6.5 & 6.0 & - \\
21 & 179 & 177 & $* * *$ \\
22 & 178 & 176 & $*$ \\
23 & 226 & 223 & $*$ \\
24 & 225 & 221 & $*$ \\
25 & 19 & 20 & - \\
26 & 19 & 19 & $* * *$ \\
27 & 49 & 53 & $* * *$ \\
28 & 49 & 53 & $* *$ \\
29 & 39 & 40 & \\
\hline
\end{tabular}

Note: significance levels $*-\mathrm{P}<0.05,{ }^{* *}-\mathrm{P}<0.01, * * *+\mathrm{P}<0.001,-$ significance levels $\mathrm{P}>0.05$.

Along the axis, the body of mite becomes more elongated and the number of pores on the ventral shield decreases. Thus, it can be said that characteristics of the summer morphotype are found farther from the starting point of the axis.

Analysis of the classification matrix showed that there are $20.7 \%$ of mites of summer morphotype in the winter generation, and $20.2 \%$ of mites with winter morphotype in the summer generation (Table 5). 
Table 4

Results of discriminant analysis of morphological characters of female Varroa destructor in seasonal samples

\begin{tabular}{cccc}
\hline Characters & Winter-summer & Characters & Winter-summer \\
\hline 1 & $3.157^{* *}$ & 16 & $0.065^{*}$ \\
2 & -0.743 & 17 & -0.027 \\
3 & -0.019 & 18 & $-0.289^{* * *}$ \\
4 & $0.080^{* *}$ & 19 & $-0.181^{* * *}$ \\
5 & -0.832 & 20 & -0.049 \\
6 & -2.038 & 21 & -0.972 \\
7 & -0.194 & 22 & -1.056 \\
8 & -1.839 & 23 & -1.742 \\
9 & $6.537^{* * *}$ & 24 & -2.088 \\
10 & $2.288^{* *}$ & 25 & 0.363 \\
11 & $-1.146^{* * *}$ & 26 & -0.120 \\
12 & -0.780 & 27 & $2.101^{* * *}$ \\
13 & -0.326 & 28 & $1.913^{* * *}$ \\
14 & 0.570 & 29 & $0.543^{*}$ \\
15 & 1.445 & Total, $\%$ & 1.000 \\
\hline
\end{tabular}

Note: significance levels ${ }^{*}-\mathrm{P}<0.05,{ }^{* *}-\mathrm{P}<0.01,{ }^{* * *}-\mathrm{P}<0.001$.

Table 5

Classification matrix of the female Varroa destructor of seasonal samples

\begin{tabular}{lccc}
\hline \multicolumn{1}{c}{ Groups } & Winter & Summer & Total \\
\hline Winter & 96 & 25 & 121 \\
Summer & 24 & 95 & 119 \\
Total & 120 & 120 & 240 \\
\hline
\end{tabular}

The plot of mites of summer and winter generations is shown on Figure 3. It can be seen that the studied samples are clearly distinguished, yet in each morphotype there are mites of the other generation.

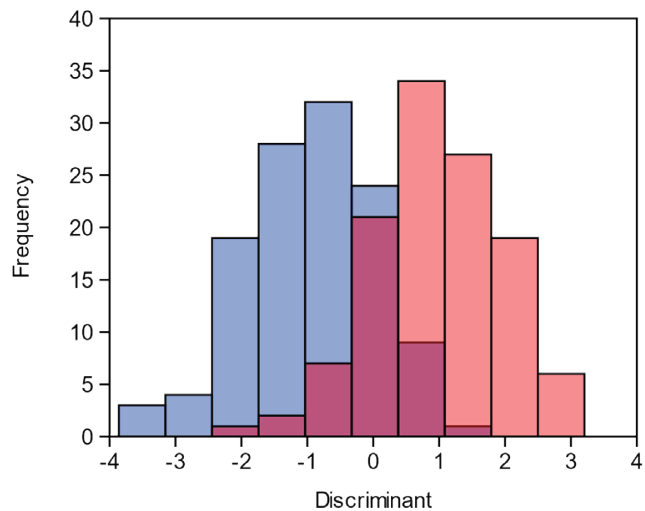

Fig. 3. Distribution of Varroa destructor females of winter and summer generations (winter sample is to the left, summer sample is to the right)

The results of dispersion analysis of the morphological characters of seasonal mite samples showed that the dispersion between the winter and summer females is higher in summer mites by eight characters (number of pores of sternal shield (18-19); length of tarsus IV (21-22); length of macrochaeta IV (23-24); distance between second and third setae of hypostome (27); distance between the third pairs of setae of hypostome (29)). In contrast, the dispersion is higher in winter mites only by four characters (length of dorsal shield (1); width of genitoventral shield (9); distance between the first and second setae of hypostome (25); distance between the second and third setae of hypostome (28), Hotelling's 204.1; $\mathrm{P}<0.001$ ). Thus the dispersion of characters is higher in summer mites by more characters compared to the winter generation of mites (Table 6).

Hence, the data, obtained with various methods of variance statistics, show the significant differences between the summer and winter morphotypes of $V$. destructor female mites by a complex of morphological characters. Moreover, the ratio of these morphotypes changes regularly in different seasons.

\section{Discussion}

According to our study, there are significant differences between $V$. destructor females of winter and summer generations by a complex of morphological characters. The summer generation of mites is charac- terized by smaller sizes, transversally elongated body, larger genitoventral shield, fewer pores of the sternal shield, shorter legs and high dispersion of most of the characters. The winter mites, conversely, are larger, elongated, with smaller genitoventral shield, more pores of the sternal shield, longer legs, and their characters are more stable. The highest number of differences between the mites of winter and summer samples is found using the dispersion analysis: there are statistically significant differences by 12 morphological characters: width of dorsal shield (character 1), width of dorsoventral shield (character 9), number of pores of sternal shield (characters 18, 19), length of tarsus and macrochaeta IV (characters 21-24), distance between the gnathosome setae (characters 25 , 27-29).

Table 6

Comparison of characters of Varroa destructor females in seasonal samples

\begin{tabular}{cccccc}
\hline Characters & Winter & Summer & Characters & Winter & Summer \\
\hline 1 & $24.24^{* * *}$ & 22.36 & 23 & 11.09 & $13.35^{* * *}$ \\
9 & $27.12^{* *}$ & 19.14 & 24 & 12.62 & $13.08^{* *}$ \\
18 & 1.10 & $1.26^{* *}$ & 25 & $2.57^{* *}$ & 2.09 \\
19 & 1.02 & $1.49^{*}$ & 27 & 6.25 & $6.48^{* *}$ \\
21 & 3.40 & $4.66^{* *}$ & 28 & $6.39^{* *}$ & 6.19 \\
22 & 3.80 & $5.13^{* * *}$ & 29 & 2.82 & $3.20^{* * *}$ \\
\hline
\end{tabular}

Note: significance levels $*-\mathrm{P}<0.05, * *-\mathrm{P}<0.01, * * *-\mathrm{P}<0.001$.

According to the literature data, even though the external parasite $V$. destructor is almost cosmopolite, it is affected by various environmental conditions mostly indirectly, through the microclimate conditions of beehives. The full life cycle of the parasitic specimens occurs in the sealed honeycombs (Adjlane et al., 2015; Seeley, 2017). Hence, the summer mites obviously have some characters by which they are better adapted to inhabiting the beehive cells in summer. The winter mites have adaptations with which they successfully reproduce in winter. There are reports of two morphotypes, summer and winter, in females of $V$. destructor mites. It has been confirmed that these mite generations differ by a complex of morphological characters, and have differing survivability in different seasons, including unequal stability of development. It has also been found that the mites of summer generation are characterized by higher dispersion of morphological characters, while characters of the winter mites are more stable (Akimov et al., 1989, 1991, 1993).

It is known that, despite the relatively stable environmental conditions of bees of the genus Apis, the reproduction activity of bees is different in winter and summer (Singh, 1962). Hence, mites stay on bees and are affected by environmental factors. Conversely, the mites which adapted to parasitism in bee cells (used for reproduction) are benefitting in more favourable conditions and reproduce better. That could have induced the specialization of the parasite and result in the development of two morphotypes. It has been shown that in $V$. destructor these morphotypes occur simultaneously (Akimov et al., 1988; Akimov \& Zaloznaya, 1996; Anderson, 2000; Maggi et al., 2009). We confirm that in our study, having found $20.7 \%$ of summer mites in the winter generation of mites, and $20.2 \%$ of winter mites in the summer generation of mites. The ratio of seasonal morphotypes in bees can be determined by different timing of their reproduction, affected by the selected variety of honey bees and the local climate conditions.

It is known that the eigenvalues of same mode in a component point to the one factor influencing the size variation of mites. That factor causes the increasing or decreasing of values for the whole complex of characters. In our work, these eigenvalues were mostly of different directions, which can point to an independent reason that affects the characters unequally. Hence, the reasons driving the changes of different morphological characters can be also different, and determined by the species' adaptation to new conditions. That adaptation can result in various forms of the morphological variation (sexual, seasonal and geographic) in that mite species. Previously it has been found that the geographic and seasonal variations manifest commensurably, meaning that the range of geographic variation of $V$. destructor characters can be found in one colony (Delfinado-Baker \& Houk, 1989; Aude et al., 2016; Dadgostar \& Nozari, 2018). Recently it was also established that the variation of mites' morphology was realized through the variation of sizes of legs, shields of ventral side, and mite body. 
That variation is the base of the morphological changes of $V$. destructor mites during their expansion to new areas (Giménez Martínez et al., 2017; Farjamfar et al., 2018). Thus, we can assume that the seasonal variation is that mobilization reserve which allowed the parasite to persist through the cyclic changes of seasons due to its colonizing a new host species and expand its range significantly.

All that can notably affect the development of new pest control measures for different seasons. Another matter to consider is the different susceptibility of summer and overwintered mites to the acaricide preparations. In different seasons, mites have different sensitivity to the chemical preparations and are unequally affected by them (Maggi et al., 2012; van Dooremalen et al., 2012). For example, the ratio of winter and summer forms in the population can be driven by either of them, in our opinion. This is even more important because the ratio of morphotypes can be changed by enhanced treatment with preparations at the moment of prevalence of a certain form. Then, the balance of forms can be disturbed. Thus, a more discerning approach to pest control should be implemented to prevent and control cases of varroosis.

\section{Conclusion}

The study of morphological variation of female $V$. destructor mites obtained from $A$. mellifera honey bees showed the significant differences between the specimens of different seasonal populations, which confirms the presence of two morphotypes of this parasitic species, the winter and the summer ones. We established the complexes of morphological characters distinguishing the summer and winter female mites. Summer females are smaller in size, elongated transversally, with larger genitoventral shield and shorter legs. Winter mites are flatter, with smaller genitoventral shield and longer legs. The observed morphotypes of $V$. destructor point to their ability for seasonal variation, with which the winter mites are better adapted to overwintering on bees, and summer mites are more suited for reproduction in bee cells during the bees' reproductive season. The morphotypes exist simultaneously in a balance described by a stable ratio. That is confirmed by our observations of $20.7 \%$ of summer mites in a winter population and $20.2 \%$ winter mites in the summer sample. These data on the presence of different morphotypes in the parasitic species require a more discerning approach to the prophylactic measures in different seasons.

\section{References}

Abou-Shaara, H. F., \& Tabikha, R. M. (2017). Morphological characterization and a morphometry map for Varroa mites from Northwest of Egypt. Cercetari Agronomice in Moldova, 49(4), 75-84.

Adjlane, N., Benaziza, D., \& Haddad, N. (2015). Population dynamic of Varroa destructor in the local honey bee Apis mellifera intermissa in Algeria. Bulletin of Pure and Applied Sciences, 34, 25-37.

Affognon, H. D., Kingori, W. S., Omondi, A. I., Diiro, M. G., Muriithi, B. W., Makau, S., \& Raina, S. K. (2015). Adoption of modern beekeeping and its impact on honey production in the former Mwingi District of Kenya: Assessment using theory-based impact evaluation approach. International Journal of Tropical Insect Science, 35(2), 96-102.

Akimov, I. A., \& Benedyk, S. V. (2004). Sravnitel'nyj analiz morfologicheskih priznakov kleshha Varroa destructor (Parasitiformes, Varroidae) iz semej bortevyh pchel Polesskogo zapovednika [Comparative analysis of morphological characters of mite Varroa destructor (Parasitiformes, Varroidae) parasitizing honeybees from hive-logs in Polessky preserve]. Vestnik Zoologii, 38(6), 57-63 (in Russian).

Akimov, I. A., \& Kiryushyn, V. E. (2010). Ethological aspects of honeybee Apis mellifera (Hymenoptera, Apidae) adaptation to parasitic mite Varroa destructor (Mesostigmata, Varroidae) invasion. Vestnik Zoologii, 44(1), 49-54.

Akimov, I. A., \& Korzh, O. P. (2012). Ecological characteristics of Varroa destructor (Parasitiformes, Varroidea) and its environmental capacity as a key factor for development of varroosis panzootia. Vestnik Zoologii, 46(5), 431-437.

Akimov, I. A., \& Zaloznaya, L. M. (1996). Izmenchivost' morfologicheskih priznakov samcov i samok kleshha Varroa [Variability of morphological characters of males and females of the mite Varroa]. Pchelovodstvo, 17, 42-46 (in Russian).

Akimov, I. A., Benedyk, S. V., \& Zaloznaya, L. M. (2004). Complex analysis of morphological characters of gamasid mite Varroa destructor (Parasitiformes, Varroidae). Vestnik Zoologii, 38(5), 57-66.
Akimov, I. A., Zaloznaya, L. M., Efimov, V. M., \& Galaktionov, Y. K. (1988). Sezonnyj polimorfizm kleshha Varroa [Seasonal polymorphism of the mite Varroa]. Pchelovodstvo, 7, 16-17 (in Russian).

Akimov, I. A., Zaloznaya, V. M., Efimov, V. M., \& Galaktionov, Y. K. (1991). Seasonal and geographical variation of morphological characters of Varroa jacobsoni (Parasitiformes,Varrodidae): Variation of mean values, standard deviations, and coefficients of fluctuating asymmetry. Entomological Review, 70(1), 106-117.

Akimov, I. A., Zalyuznaya, L. M., Efimov, V. M., \& Galaktionov, Y. K. (1989). Sezonnyj polimorfizm u kleshha Varroa jacobsoni Oudem., 1904 (Parasitiformes, Varroidae) [Seasonal polymorphism in Varroa jacobsoni Oudem. 1904 (Parasitiformes, Varroidae)]. Zhurnal Obshhej Biologii, 50(6), 819-823 (in Russian).

Akimov, I. A., Grobov, O. F., Piletskaya, I. V., Barabanova, V. V., Yastrebtsov, A. V., Gorgol, V. G., Zaloznaya, L. M., Galaktionov, Y. K., Efimov, V. M., \& Nepomnjashich, V. A. (1993). Pchelinyj kleshh Varroa jacobsoni [Bee mite Varroa jacobsoni]. Naukova Dumka, Kyiv (in Russian).

Akimov, I. A., Starovir, I. S., Yastrebtsov, A. V., \& Gorgol, V. G. (1988). Kleshh Varroa - vozbuditel' varroatoza pchel [The mite Varroa - pathogen of bee varroatosis]. Naukova Dumka, Kyiv (in Russian).

Akinwande, K. L., Badejo, M. A., \& Ogbogu, S. S. (2012). Incidence of the Korean haplotype of Varroa destructor in southwest Nigeria. Journal of Apicultural Research, 51(4), 369-370.

Anderson, D. L. (2000). Variation in the parasitic bee mite Varroa jacobsoni Oud. Apidologie, 31, 281-292.

Anderson, D. L., Halliday, R. B., \& Otis, G. W. (1997). The occurrence of Varroa underwoodi (Acarina: Varroidae) in Papua New Guinea and Indonesia. Apidologie, 28, 143-147.

Anderson, D., \& Trueman, J. (2000). Varroa jacobsoni (Acari: Varroidae) is more than one species. Experimental and Applied Ácarology, 24, 165-189.

Aude, K. E., Armand, P., Francoi, A., Charlemagne, G., Georg, G., Manuelle, T., \& Lamine, B.-M. (2016). Morphometric characterization of parasite Varroa sp. of bee Apis mellifera L. in Benin. European Scientific Journal, 12(33), 221-234.

Bloch, G., \& Grozinger, C. M. (2011). Social molecular pathways and the evolution of bee societies. Philosophical Transactions of The Royal Society B Biological Sciences, 366(1574), 2155-2170.

Boecking, O., \& Genersch, E. (2008). Varroosis - the ongoing crisis in bee keeping. Journal für Verbraucherschutz und Lebensmittelsicherheit, 3, 221-228.

Dadgostar, S., \& Nozari, J. (2018). Classical and geometric morphometric methods reveal differences between specimens of Varroa destructor (Mesostigmata: Varroidae) from seven provinces of Iran. Persian Journal of Ácarology, 7(1), 51-60.

Dahle, B. (2010). The role of Varroa destructor for honey bee colony losses in Norway. Journal of Apicultural Research and Bee World, 49, 124-125.

Delaney, D. A., Keller, J. J., Caren, J. R., \& Tarpy, D. R. (2010). The physical, insemination, and reproductive quality of honey bee queens (Apis mellifera $\mathrm{L}$.). Apidologie, 42(1), 1-13.

Delfinado, M. D. (1963). Mites of the honeybee in South-East Asia. Journal of Apicultural Research, 2, 113-114.

Delfinado, M., \& Houck, M. (1989). Geographic variation in Varroa jacobsoni (Acari, Varroidae): Application of multivariate morphometric techniques. Apidologie, 20, 345-358.

Delfinado-Baker, M. D. (1988). Variability and biotypes of Varroa jacobsoni Oudemans. American Bee Journal, 128, 567-568.

Farjamfar, M., Saboori, A., Nozari, J., \& Hosseininaveh, V. (2018). Morphometric analysis in different geographical populations of Varroa destructor (Acari: Varroidae) associated with Apis mellifera colonies in Iran. Systematic and Applied Acarology, 23(10), 1915-1930.

Giménez Martínez, P., Mendoza, Y., Invenizzi, C., Fuselli, S., Alonso Salces, R., Fernández Iriarte, P., \& Maggi, M. (2017). Morphometric correlation between Apis mellifera morphotypes (Hymenoptera) and Varroa destructor (Acari) from Uruguay. Journal of Apicultural Research, 56(2), 122-129.

Griffits, D. A., \& Bowman, C. E. (1981). World distribution of the mites Varroa jacobsoni a parasite of honeybees. Bee World, 62(4), 154-163.

Hammer, Ø., Harper, D. A. T., \& Ryan, P. D. (2001). PAST: Paleontological statistics software package for education and data analysis. Palaeontologia Electronica, 4(1), 1-9.

Hewlett, S. E., Wareham, D. M., \& Barron, A. B. (2018). Honey bee (Apis mellifera) sociability and nestmate affiliation are dependent on the social environment experienced post-eclosion. Journal of Experimental Biology, 221(3), 173054.

Kovalchuk, I., Dvylyuk, I., Lecyk, Y., Dvylyuk, I., \& Gutyj, B. (2019). Physiological relationship between content of certain microelements in the tissues of different anatomic sections of the organism of honey bees exposed to citrates of argentum and cuprum. Regulatory Mechanisms in Biosystems, 10(2), 177-181.

Kovalskyi, Y., Gucol, A., Gutyj, B., Sobolev, O., Kovalska, L., \& Mironovych, A. (2018). Features of histolism and hystogenesis in the vital temperature range 
in the organism of honey bee (Apis mellifera L.) in the postembrional period. Ukrainian Journal of Ecology, 8(2), 301-307.

Kuznetsov, V. N. (2005). Kitajskaja voskovaja pchela Apis cerana cerana F. (Hymenoptera, Apidae) na Dal'nem Vostoke Rossii [Chinese wax bee Apis cerana cerana F. (Hymenoptera, Apidae) in Russian Far East]. Tovarishhestvo Nauchnyh Zdanij KMK, Moscow (in Russian).

Kuznetsov, V. N., \& Lelej, A. S. (2005). O parazitirovanii kleshhej roda Varroa Oudemans, 1904 (Acari: Varroidea) na kitajskoj voskovoj pchele Apis cerana cerana Fabricius, 1793 (Hymenoptera: Apidae) v Primorskom krae [On parasitizing of mites from genus Varroa Oudemans, 1904 (Acari: Varroidae) on Chinese wax bee Apis cerana Fabricius, 1793 (Hymenoptera: Apidae) in Primorsk area in Russia]. Chtenija Pamjati A. I. Kurencova, 16, 39 -46 (in Russian).

Le Conte, Y., Ellis, M., \& Ritter, W. (2010). Varroa mites and honey bee health: Can Varroa explain part of the colony losses? Apidologie, 41(3), 353-363.

Lekprayoon, C., \& Tangkanasing, P. (1991). Euvarroa wongsirii, a new species of bee mite from Thailand. International Journal of Acarology, 17(4), 255-258.

Maggi, M. D., Sardella, N. H., Ruffinengo, S. R., \& Eguaras, M. J. (2009). Morphotypes of Varroa destructor collected in Apis mellifera colonies from different geographic locations of Argentina. Parasitology Research, 105(6), 1629-1636.

Maggi, M., Peralta, L., Ruffinengo, S., Fuselli, S., \& Eguaras, M. (2012). Body size variability of Varroa destructor and its role in acaricide tolerance. Parasitology Research, 110(6), 2333-2340.

Mossadegh, M. S. (1990). Development of Euvarroa sinhai (Acarina: Mesostigmata) a parasitic mite of Apis florea on Apis mellifera worker brood. Experimental and Applied Acarology, 9, 73-78.

Nanork, P., Wongsiri, S., \& Oldroyd, B. P. (2007). Preservation and loss of the honey bee (Apis) egg-marking signal across evolutionary time. Behavioral Ecology and Sociobiology, 61(10), 1509-1514.

Nazzi, F., \& Le Conte, Y. (2016). Ecology of Varroa destructor, the major ectoparasite of the western honey bee, Apis mellifera. Annual Review of Entomology, 61, 417-432.

Nazzi, F., Brown, S. P., Annoscia, D., Del Piccolo, F., Di Prisco, G., Varricchio, P., Vedova, G. D., Cattonaro, F., Caprio, E., \& Pennacchio, F. (2012). Synergistic parasite-pathogen interactions mediated by host immunity can drive the collapse of honeybee colonies. PLoS Pathogens, 8, e1002735.

Oddie, M. A. Y., Neumann, P., \& Dahle, B. (2019). Cell size and Varroa destructor mite infestations in susceptible and naturally-surviving honeybee (Apis mellifera) colonies. Apidologie, 50(1), 1-10.
Oldroyd, B. P. (1999). Coevolution while you wait: Varroa jacobsoni, a new parasite of western honeybees. Trends in Ecology and Evolution, 14, 312-315.

Otis, G., \& Kraly, J. (2001). Mites of economic importance not present in North America in mites of the honey bee. Dadant \& Sons, Hamilton.

Oudemans, A. C. (1904). On a new genus and species of parasitic acari. Notes from the Leyden Museum, 24, 216-222.

Peng, Y.-S., Fang, Y., Xu, S., \& Ge, L. (1987). The resistance mechanism of the Asian honey bee, Apis cerana Fabr., to an ectoparasitic mite, Varroa jacobsoni Oudemans. Journal of Invertebrate Pathology, 49, 54-60.

Rath, W. (1999). Co-adaptation of Apis cerana Fabr. and Varroa jacobsoni Oud. Apidologie, 30, 97-110

Rinkevich, F. D., Danka, R. G., \& Healy, K. B. (2017). Influence of Varroa mite (Varroa destructor) management practices on insecticide sensitivity in the honey bee (Apis mellifera). Insects, 8(1), e9.

Rosenkranz, P., Aumeier, P., \& Ziegelmann, B. (2010). Biology and control of Varroa destructor. Journal of Invertebrate Pathology, 103, 96-119.

Seeley, T. D. (2017). Life-history traits of wild honey bee colonies living in forests around Ithaca, NY, USA. Apidologie, 48(6), 743-754.

Shell, W. A., \& Rehan, S. M. (2018). Behavioral and genetic mechanisms of social evolution: Insights from incipiently and facultatively social bees. Apidologie, 49(1), 13-30.

Singh, S. (1962). Beekeeping in India. Indian Council of Agricultural Research, New Delhi.

Van Dooremalen, C., Gerritsen, L. J. M., Cornelissen, B., van der Steen, J. J. M., van Langevelde, F., \& Blacquiere, T. (2012). Winter survival of individual honey bees and honey bee colonies depends on level of Varroa destructor infestation. PLoS One, 7(4), e36285.

Vishchur, V. Y., Gutyj, B. V., Nischemenko, N. P., Kushnir, I. M., Salata, V. Z., Tarasenko, L. O., Khimych, M. S., Kushnir, V. I., Kalyn, B. M., Magrelo, N. V., Boiko, P. K., Kolotnytskyy, V. A., Velesyk, T., Pundyak, T. O., \& Gubash, O. P. (2019). Effect of industry on the content of fatty acids in the tissues of the honey-bee head. Ukrainian Journal of Ecology, 9(3), 174-179.

Woo, K. S. (1992). New honeybee mite Varroa underwoodi on Apis cerana in South Korea. Honeybee Science, 13, 173-174.

Zakhvatkin, A. A. (1941). Fauna SSSR. Paukoobraznye [Fauna of USSR. Arachnoidea]. Akademia Nauk SSSR, Leningrad, Moscow (in Russian). 